\title{
Chemical, Nutrient and Physicochemical Properties of Brown Seaweed, Sargassum polycystum C. Agardh (Phaeophyceae) Collected from Port Dickson, Peninsular Malaysia
}

\author{
Muhammad Farhan Nazarudin 1,*(D), Nurul Haziqah Alias ${ }^{1}$, Seentusha Balakrishnan ${ }^{1}$, \\ Wan Nurazween Izatee Wan Hasnan ${ }^{1}$ (D), Nur Amirah Izyan Noor Mazli ${ }^{1}$, Mohd Ihsanuddin Ahmad ${ }^{1}$, \\ Ina-Salwany Md Yasin ${ }^{1}$, Azizul Isha ${ }^{2}{ }^{(D)}$ and Mohamed Aliyu-Paiko ${ }^{3} \mathbb{D}$
}

1 Aquatic Animal Health and Therapeutics Laboratory (AquaHealth), Institute of Bioscience, Universiti Putra Malaysia, Serdang 43400, Malaysia; nhaziqahalias95@gmail.com (N.H.A.); seentusha@gmail.com (S.B.); wannurazween98@gmail.com (W.N.I.W.H.); nuramirahizyan@gmail.com (N.A.I.N.M.); mia.abdullah5311@gmail.com (M.I.A.); salwany@upm.edu.my (I.-S.M.Y.)

2 Laboratory of Natural Medicines and Products Research, Institute of Bioscience, Universiti Putra Malaysia, Serdang 43400, Malaysia; azizul_isha@upm.edu.my

3 Biochemistry Department, Ibrahim Badamasi Babangida University (IBBU), Lapai 911101, Nigeria; mo.aleeyu.paiko@gmail.com

check for updates

Citation: Nazarudin, M.F.; Alias, N.H.; Balakrishnan, S.; Wan Hasnan, W.N.I.; Noor Mazli, N.A.I.; Ahmad, M.I.; Md Yasin, I.-S.; Isha, A.; Aliyu-Paiko, M. Chemical, Nutrient and Physicochemical Properties of Brown Seaweed, Sargassum polycystum C. Agardh (Phaeophyceae) Collected from Port Dickson, Peninsular Malaysia. Molecules 2021, 26, 5216. https://doi.org/10.3390/ molecules 26175216

Academic Editor: Eric Deslandes

Received: 7 June 2021

Accepted: 30 June 2021

Published: 27 August 2021

Publisher's Note: MDPI stays neutral with regard to jurisdictional claims in published maps and institutional affiliations.

Copyright: (c) 2021 by the authors. Licensee MDPI, Basel, Switzerland. This article is an open access article distributed under the terms and conditions of the Creative Commons Attribution (CC BY) license (https:/ / creativecommons.org/licenses/by/ $4.0 /)$.
* Correspondence: m_farhannaza@upm.edu.my; Tel.: +60-397-692-237

\begin{abstract}
Recent increased interest in seaweed is motivated by attention generated in their bioactive components that have potential applications in the functional food and nutraceutical industries. In the present study, nutritional composition, metabolite profiles, phytochemical screening and physicochemical properties of freeze-dried brown seaweed, Sargassum polycystum were evaluated. Results showed that the S. polycystum had protein content of $8.65 \pm 1.06 \%$, lipid of $3.42 \pm 0.01 \%$, carbohydrate of $36.55 \pm 1.09 \%$ and total dietary fibre content of $2.75 \pm 0.58 \%$ on dry weight basis. The mineral content of S. polycystum including $\mathrm{Na}, \mathrm{K}, \mathrm{Ca}, \mathrm{Mg} \mathrm{Fe}$, Se and Mn were 8876.45 $\pm 0.47,1711.05 \pm 0.07$, $1079.75 \pm 0.30,213.85 \pm 0.02,277.6 \pm 0.12,4.70 \pm 0.00$ and $4.45 \pm 0.00 \mathrm{mg} 100 / \mathrm{g}$ DW, respectively. Total carotenoid, chlorophyll $a$ and $b$ content in $S$. polycystum were detected at $45.28 \pm 1.77,141.98 \pm 1.18$ and $111.29 \mu \mathrm{g} / \mathrm{g}$ respectively. The total amino acid content was $74.90 \pm 1.45 \%$. The study revealed various secondary metabolites and major constituents of $S$. polycystum fibre to include fucose, mannose, galactose, xylose and rhamnose. The metabolites extracted from the seaweeds comprised n-hexadecanoic acid, 1,2-benzenedicarboxylic acid, mono(2-ethylhexyl) ester, benzenepropanoic acid, 3,5-bis(1,1-dimethylethyl)-4-hydroxy- methyl ester, 1-dodecanol, 3,7,11-trimethyl-, which were the most abundant. The physicochemical properties of $S$. polycystum such as water-holding and swelling capacity were comparable to several commercial fibre-rich products. In conclusion, results of this study indicate that $S$. polycystum is a potential candidate as functional food sources for human consumption and its cultivation needs to be encouraged.
\end{abstract}

Keywords: metabolite profile; phytochemical; physicochemical; Sargassum polycystum; seaweed

\section{Introduction}

Seaweeds are marine algae and sustainable resources that could be commercially cultivated in the Malaysian ecosystem. This is because Malaysia has a rich biodiversity of seaweeds that are of high nutritional value, some of which have not been previously studied. The potential of seaweeds as alternative sources for high-quality food products, fertilisers, phyco-colloids and cosmetic ingredients for the nutraceutical and pharmaceutical industries has attracted the Malaysian government to focus on increasing their production as alternative to aquaculture. This is envisaged to assist in raising household incomes through foreign exchange earnings, providing jobs, expanding alternative means of livelihoods and building business for commercial investment opportunities [1]. Recent 
increased interest in seaweed is motivated by the attention generated in their bioactive components that has potential applications in the functional food and nutraceutical industries, which are lucrative and have the incentives to reduce metabolic risk factors such as hyperglycaemia, hypercholesterolemia and hyperlipidaemia [2]. This is principally because seaweeds have been consumed as traditional cuisines in many Asian countries, which has led to their utilisation as a functional food to develop among the western countries.

The fibre components of seaweeds essentially contains structural polysaccharides such as alginate and fucoidan in brown seaweed, carageenan, agar and porphyran rich in red seaweeds and ulvan found in green seaweeds. Seaweeds also contain high amounts of minerals due to their natural marine habitat, where the diversity of the minerals they absorb has been noticed to be wide. Research by various workers on the relationship between the nutritional value of feeds and the cultured species of seaweeds have been demonstrated to reveal that the key factors in nutritional value are the contents of essential amino and fatty acids [3,4]. Consequently, the same ten essential amino acids, comprising the long-chain unsaturated fatty acids of the omega- 3 series are important dietary nutrients for fish, to help in the promotion of healthy growth and survival [5]. This is because many aquatic organisms have the ability to synthesise some of these compounds from precursor molecules, in limited quantities $[4,6]$.

Increasingly in recent times, micro- and macro-algae are being marketed as 'functional foods' or 'nutraceuticals'. However, these terms have no legal status in many countries, but they describe foods that contain bioactive compounds or phytochemicals that could benefit human and animal health beyond the role of basic nutrition (e.g., anti-inflammatories, disease prevention) $[7,8]$. In various studies, the potential nutritional or bioactive contents of different seaweeds have been reported. However, only a few of such studies have focused on the bioavailability of nutrients from, and phytochemicals in algal foods. Scientific experiments and studies have mostly concentrated attention predominantly on brown seaweeds and their derivatives, largely because of their perceived sustainability [9]. Therefore, the objectives of the present study were to evaluate the phytochemical composition, identify nutritionally important metabolites contained and investigate the physicochemical properties of brown seaweed, S. polycystum sampled from Port Dickson, Malaysia, as potential functional food resources. The overall aim of the study was to explore potential application of the seaweed species abundant on the coast of Peninsular Malaysia, for utilisation as functional food, in order to promote the commercial cultivation of the species.

\section{Results}

\subsection{Proximate Composition}

Results determining the proximate composition of brown seaweed, S. polycystum, are as shown in Table 1. Although the moisture content was low, recorded as $13.70 \pm 0.14 \% \mathrm{DW}$, ash content was high at $21.38 \pm 0.17 \%$ DW. Content of protein in S. polycystum was relatively appreciable, at $8.65 \pm 1.06 \% \mathrm{DW}$, whereas total lipids in the species in the present study was noted at $3.42 \%$ DW. Determination of crude fibre and total carbohydrate contents in S. polycystum yielded 13.55 and $36.55 \%$ DW, respectively.

Table 1. Proximate composition of ground lyophilised S. polycystum.

\begin{tabular}{cc}
\hline Composition & \% DW \\
\hline Moisture & $13.70 \pm 0.14$ \\
Ash & $21.38 \pm 0.17$ \\
Protein & $8.65 \pm 1.06$ \\
Lipid & $3.42 \pm 0.01$ \\
Crude fibre & $13.55 \pm 0.14$ \\
Carbohydrate & $36.55 \pm 1.09$ \\
Total Dietary fibre & $2.75 \pm 0.58$ \\
\hline
\end{tabular}

Values are mean \pm SEM, $n=3$. Dry weight (DW). 


\subsection{Contents of Total Carotenoids and Chlorophylls}

Results for the major photosynthetic pigments studied in seaweeds are usually presented as content of total carotenoids, chlorophylls $a$ and $b$, and expressed as $\mu \mathrm{g} / 100 \mathrm{~g}$ dry weight (DW). The values for total carotenoids, chlorophyll $a$ and chlorophyll $b$ content determined in the S. polycystum are shown in Table 2. From the table, it may be observed that the concentration of total carotenoids measured $45.28 \pm 1.77 \mu \mathrm{g} / 100 \mathrm{~g}$ DW, whereas chlorophyll $a$ and chlorophyll $b$ contents measured $141.98 \pm 1.18 \mu \mathrm{g} / 100 \mathrm{~g}$ DW and $111.29 \mu \mathrm{g} / 100 \mathrm{~g} \mathrm{DW}$, respectively.

Table 2. Content of total carotenoids, chlorophyll $a$ and chlorophyll $b$ in extracts of s elected seaweed species sampled in the Malaysian Peninsular.

\begin{tabular}{cccc}
\hline Seaweed Species & $\begin{array}{c}\text { Total Carotenoids } \\
(\mu \mathrm{g} / \mathbf{1 0 0} \mathbf{g} \text { DW })\end{array}$ & $\begin{array}{c}\text { Chlorophyll } \boldsymbol{a} \\
(\boldsymbol{\mu g} / \mathbf{1 0 0} \mathbf{g} \text { DW })\end{array}$ & $\begin{array}{c}\text { Chlorophyll } \boldsymbol{b} \\
(\boldsymbol{\mu g} / \mathbf{1 0 0} \mathbf{g} \text { DW })\end{array}$ \\
\hline S. polycystum & $45.28 \pm 1.77$ & $141.98 \pm 1.18$ & $111.29 \pm 2.28$ \\
\hline Values are expressed as mean \pm SEM of three (3) replicate measurements $(n=3)$, dry weight basis.
\end{tabular}

\subsection{Mineral Content}

Results for measurement of mineral content of S. polycystum is presented in Table 3. Sodium, Na (8876.45 mg 100/g DW) was detected as the most abundant element in the seaweed, followed by potassium, K (1711.05 mg 100/g DW), calcium, Ca (1079.75 mg 100/g DW) and magnesium, Mg (213.85 mg 100/g DW). The detection of Fe, Se and Mn in S. polycystum in the present study were in trace quantities, at $277.60,4.70$ and $4.45 \mathrm{mg}$ $100 / g$ DW, respectively.

Table 3. Mineral content of brown seaweed, S. polycystum.

\begin{tabular}{cc}
\hline Minerals & mg/100g DW \\
\hline $\mathrm{Na}$ & $8876.45 \pm 0.47$ \\
$\mathrm{~K}$ & $1711.05 \pm 0.07$ \\
$\mathrm{Mg}$ & $213.85 \pm 0.02$ \\
$\mathrm{Ca}$ & $1079.75 \pm 0.30$ \\
$\mathrm{Fe}$ & $277.60 \pm 0.12$ \\
$\mathrm{Se}$ & $4.70 \pm 0.01$ \\
$\mathrm{Mn}$ & $4.45 \pm 0.01$ \\
$\mathrm{P}$ & $19,108.25 \pm 0.70$ \\
Na/K ratio & $5.19 \pm 2.59$ \\
Total cation & $31,276.10 \pm 1.67$
\end{tabular}

Values are mean \pm SEM, $n=3$. Dry weight (DW); sodium (Na); potassium (K); magnesium. (Mg); calcium (Ca); iron $(\mathrm{Fe})$; selenium $(\mathrm{Se})$; manganese $(\mathrm{Mn})$; phosphorus $(\mathrm{P})$.

\subsection{Fucose-Containing Sulfated Polysaccharides from S. polycystum}

Composition analysis of monosacharides from brown seaweed, S. polycystum have been shown to be made up principally of fucose, with minor quantities of other monosaccharides, especially xylose, galactose, mannose and rhamnose, as shown in Table 4 . From results of the present study, fucose was the highest monosaccharide $(23.00 \pm 0.02 \mu \mathrm{g} / \mathrm{mL})$ in S. polycystum compared to rhamnose $(0.30 \pm 0.17 \mu \mathrm{g} / \mathrm{mL})$; the lowest. Mannose and galactose were however, measured as $0.45 \pm 0.02$ and $0.75 \pm 0.23 \mu \mathrm{g} / \mathrm{mL}$, respectively.

\subsection{Phytochemical Screening}

Tests on the methanolic extract of S. polycystum revealed it to contain steroids, phenols, tannins, saponins, flavonoids, terpenoids and glycosides, as shown in Table 5. The qualitative test results for these substances confirmed the presence of the different secondary metabolites, as all were positive. 
Table 4. Monosaccharides composition of fucose-containing sulphated polysaccharides in S. polycystum ( $\mu \mathrm{g} / \mathrm{mL})$.

\begin{tabular}{cc}
\hline Monosacharide & Composition $(\boldsymbol{\mu g} / \mathbf{m L})$ \\
\hline Fucose & $23.00 \pm 0.02$ \\
Mannose & $0.45 \pm 0.02$ \\
Galactose & $0.75 \pm 0.23$ \\
Xylose & $1.00 \pm 0.04$ \\
Rhamnose & $0.30 \pm 0.17$ \\
\hline
\end{tabular}

Values are mean \pm SEM, $n=3$.

Table 5. Phytochemicals from S. polycystum.

\begin{tabular}{cccccccc}
\hline Metabolites & Steroid & Phenol & Tannins & Saponins & Flavonoids & Terpenoids & Glycosides \\
\hline S. polycystum & + & + & + & + & + & + & + \\
\hline
\end{tabular}

(+) presence, of tested metabolite.

\subsection{Amino Acid Profiles}

Analytical result of amino acids measured in S. polycystum is as shown in Table 6, confirming the presence of 15 amino acids with clearly resolved separations. Content of total amino acids detected in the present study measured $74.90 \pm 1.45 \mathrm{mg} \mathrm{g}^{-1} \mathrm{DW}$. The seaweed sample revealed the presence of all essential amino acids (EAAs) in different proportions, except tryptophan, which was most likely destroyed during acid hydrolysis. The total essential amino acids (EAAs) content in S. polycystum measured $37.28 \%$, where the highest essential amino acid was noted to be leucine and the most limiting was methionine, followed by thyrosine. Although the ratio of essential amino acids to total amino acids was approximately 0.50, that for EAAs to NEAAs in the seaweed sample was about 1.00 .

Table 6. Amino acid content of S. polycystum.

\begin{tabular}{|c|c|}
\hline Amino Acid & mg/g DW \\
\hline Arginine, Arg $^{a}$ & $4.32 \pm 0.14$ \\
\hline Thyrosine, Tyr ${ }^{\text {a }}$ & $1.55 \pm 0.03$ \\
\hline Threonine, $\mathrm{Thr}^{\mathrm{a}}$ & $3.72 \pm 0.03$ \\
\hline Valine, $\mathrm{Val}^{\mathrm{a}}$ & $5.58 \pm 0.13$ \\
\hline Methionine, Met ${ }^{\mathrm{a}}$ & $1.25 \pm 0.01$ \\
\hline Lysine, Lys a & $3.7 \pm 0.02$ \\
\hline Isoleusine, Ile $^{\text {a }}$ & $4.63 \pm 0.10$ \\
\hline Leucine, Leu a & $7.57 \pm 0.19$ \\
\hline Phenylalanine, Phe & $4.95 \pm 0.13$ \\
\hline Alanine, Ala & $5.78 \pm 0.14$ \\
\hline Aspartic, acid, Asp & $7.47 \pm 0.14$ \\
\hline Glutamic acid, Glu & $10.01 \pm 0.20$ \\
\hline Serine, Ser & $4.96 \pm 0.13$ \\
\hline Glycine, Gly & $5.43 \pm 0.06$ \\
\hline Proline, Pro & $3.94 \pm 0.05$ \\
\hline Total AAs & $74.90 \pm 1.45$ \\
\hline Total EAAs & $37.28 \pm 0.78$ \\
\hline Total NEAAs & $37.63 \pm 0.74$ \\
\hline EAAs/Total AAs & $0.50 \pm 0.54$ \\
\hline EAAs/NEAAs & $1.00 \pm 1.05$ \\
\hline
\end{tabular}

Values are mean \pm SEM, $n=3$. Dry weight (DW); amino acids (AAs); essential amino acids (EAAs); non-essential

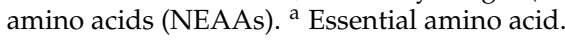

\subsection{Metabolite Profiling of S. polycystum}

GC-MS analysis of S. polycystum yielded 22 metabolites to be identified. These metabolites are of varied chemical classes and most have been reported to exhibit important biological activities. These identified metabolites also include various aliphatic acids and 
aromatic compounds in the different samples. The identified metabolites with retention times (RT), peak areas (\%) and molecular formula are as shown in Table 7.

Table 7. Metabolite profile of S. Polycystum.

\begin{tabular}{|c|c|c|c|c|}
\hline No & Name & $\begin{array}{l}\text { Retention } \\
\text { Time (min) }\end{array}$ & Area $\%$ & $\begin{array}{l}\text { Molecular } \\
\text { Formula }\end{array}$ \\
\hline 1 & $\begin{array}{c}\text { Phenol } \\
\text { Phenol, 3,5-bis(1,1-dimethylethyl)- } \\
\text { Ketone }\end{array}$ & 15.983 & 3.62 & $\mathrm{C}_{14} \mathrm{H}_{22} \mathrm{O}$ \\
\hline 2 & $\begin{array}{c}\text { 2-Pentadecanone, 6,10,14-trimethyl- } \\
\text { Aldehyde }\end{array}$ & 19.698 & 0.69 & $\mathrm{C}_{18} \mathrm{H}_{36} \mathrm{O}$ \\
\hline 3 & E-14-Hexadecenal & 16.904 & 1.01 & $\mathrm{C}_{16} \mathrm{H}_{30} \mathrm{O}$ \\
\hline 4 & $\begin{array}{l}\text { Octadecanal } \\
\text { Alcohol }\end{array}$ & 17.937 & 0.43 & $\mathrm{C}_{18}^{10} \mathrm{H}_{36} \mathrm{O}$ \\
\hline 5 & 3,7,11,15-Tetramethyl-2-hexadecen-1-ol & 20.067 & 2.27 & $\mathrm{C}_{20} \mathrm{H}_{40} \mathrm{O}$ \\
\hline 6 & $\begin{array}{c}\text { 1-Dodecanol, 3,7,11-trimethyl- } \\
\text { Hydrocarbons }\end{array}$ & 22.341 & 4.26 & $\mathrm{C}_{15} \mathrm{H}_{32} \mathrm{O}$ \\
\hline 7 & 1-Hexadecene & 14.384 & 0.51 & $\mathrm{C}_{14} \mathrm{H}_{28}$ \\
\hline 8 & 1-Octadecene & 19.161 & 0.83 & $\mathrm{C}_{18} \mathrm{H}_{36}$ \\
\hline 9 & $\begin{array}{l}\text { 1-Nonadecene } \\
\text { Fatty acids }\end{array}$ & 21.206 & 0.30 & $\mathrm{C}_{19} \mathrm{H}_{38}$ \\
\hline 10 & Tetradecanoic acid & 18.913 & 1.74 & $\mathrm{C}_{14} \mathrm{H}_{28} \mathrm{O}_{2}$ \\
\hline 11 & $n$-Hexadecanoic acid & 21.027 & 10.35 & $\mathrm{C}_{16} \mathrm{H}_{32} \mathrm{O}_{2}$ \\
\hline 12 & cis-Vaccenic acid & 22.692 & 3.37 & $\mathrm{C}_{18}^{16} \mathrm{H}_{34} \mathrm{O}_{2}$ \\
\hline 13 & $\begin{array}{l}\text { 15-Hydroxypentadecanoic acid } \\
\text { Sterols }\end{array}$ & 24.005 & 1.49 & $\mathrm{C}_{15} \mathrm{H}_{30} \mathrm{O}_{3}$ \\
\hline 14 & Stigmasta-5,22-dien-3-ol, acetate, $(3 \beta)$ - & 30.024 & 0.83 & $\mathrm{C}_{31} \mathrm{H}_{50} \mathrm{O}_{2}$ \\
\hline 15 & Cholest-4-en-3-one & 31.086 & 0.87 & $\mathrm{C}_{27} \mathrm{H}_{44} \mathrm{O}$ \\
\hline 16 & $\begin{array}{l}\text { Stigmasta-4,24(28)-dien-3-one, (24E)- } \\
\text { Fatty acid methyl/ethyl esters }\end{array}$ & 32.357 & 1.52 & $\mathrm{C}_{29} \mathrm{H}_{46} \mathrm{O}$ \\
\hline 17 & Tridecanoic acid, 12-methyl-, methyl ester & 18.427 & 0.53 & $\mathrm{C}_{15} \mathrm{H}_{30} \mathrm{O}_{2}$ \\
\hline 18 & $\begin{array}{l}\text { Hexadecanoic acid, 2,3-dihydroxypropyl ester } \\
\text { Other }\end{array}$ & 25.319 & 0.66 & $\mathrm{C}_{19} \mathrm{H}_{38} \mathrm{O}_{4}$ \\
\hline 19 & Benzenepropanoic acid, 3,5-bis(1,1-dimethylethyl)-4-hydroxy-, methyl ester & 20.645 & 7.03 & $\mathrm{C}_{18} \mathrm{H}_{28} \mathrm{O}_{3}$ \\
\hline 20 & Hexadecanoic acid, 2-hydroxy-1-(hydroxymethyl)ethyl ester & 23.601 & 1.17 & $\mathrm{C}_{19} \mathrm{H}_{38} \mathrm{O}_{4}$ \\
\hline 21 & 1,2-Benzenedicarboxylic acid, mono(2-ethylhexyl) ester & 25.946 & 7.69 & $\mathrm{C}_{16} \mathrm{H}_{22} \mathrm{O}_{4}$ \\
\hline 22 & Squalene & 27.992 & 0.74 & $\mathrm{C}_{30} \mathrm{H}_{50}$ \\
\hline
\end{tabular}

Among those metabolites identified in S. polycystum (Table 7), the four most abundant recorded are $n$-hexadecanoic acid $(10.35 \%), 1,2$-benzenedicarboxylic acid, mono(2ethylhexyl) ester (7.69\%), benzenepropanoic acid, 3,5-bis(1,1-dimethylethyl)-4-hydroxymethyl ester (7.03\%), 1-dodecanol, 3,7,11-trimethyl-(4.26\%). Other important metabolites identified in S. ilicifolium are phenol, 3,5-bis(1,1-dimethylethyl)-(6.54\%) and 3,7,11,15tetramethyl-2-hexadecen-1-ol (6.24\%), hexadecanoic acid, methyl ester (5.28\%), 3,7,11,15tetramethyl-2-hexadecen-1-ol (2.27\%) and Squalene (0.74\%).

\subsection{Physicochemical Properties}

Evaluation of physicochemical properties of S. polycystum revealed differences in the various parameters measured based on temperature, as shown in Table 8. At room temperature $\left( \pm 25^{\circ} \mathrm{C}\right)$, swelling capacity, SWC was measured as $10.27 \pm 0.25 \mathrm{~mL} / \mathrm{g} \mathrm{DW}$, which increased slightly when temperature was raised to $37^{\circ} \mathrm{C}(10.43 \pm 0.12 \mathrm{~mL} / \mathrm{g}$ DW $)$ and returned to the original value noted at room temperature $(10.27 \pm 0.25 \mathrm{~mL} / \mathrm{g} \mathrm{DW})$ at the highest temperature of evaluation $\left(80^{\circ} \mathrm{C}\right)$. The water-holding capacity, WHC on the other hand, was measured as $2.76 \pm 1.02 \mathrm{~g} / \mathrm{g}$ DW at room temperature but increased to $4.10 \pm 0.84 \mathrm{~g} / \mathrm{g} \mathrm{DW}$ at $37{ }^{\circ} \mathrm{C}$ before decreasing to $2.89 \pm 0.86 \mathrm{~g} / \mathrm{g} \mathrm{DW}$ and $2.90 \pm 0.69 \mathrm{~g} / \mathrm{g}$ DW at $60^{\circ} \mathrm{C}$ and $80^{\circ} \mathrm{C}$, respectively. Oil-holding capacity, $\mathrm{OHC}$ of the seaweed was measured as lowest at $80{ }^{\circ} \mathrm{C}$ and room temperature, but highest at $60{ }^{\circ} \mathrm{C}$ and $37^{\circ} \mathrm{C}$. 
Table 8. The SWC, WHC and OHC of S. polycystum at various temperatures.

\begin{tabular}{ccccc}
\hline Parameters & RT & $\mathbf{3 7}{ }^{\circ} \mathbf{C}$ & $\mathbf{6 0}^{\circ} \mathbf{C}$ & $\mathbf{8 0}^{\circ} \mathbf{C}$ \\
\hline SWC (mL/g DW) & $10.27 \pm 0.25$ & $10.43 \pm 0.12$ & $10.17 \pm 0.29$ & $10.27 \pm 0.06$ \\
WHC (g/g DW) & $2.76 \pm 1.02$ & $4.10 \pm 0.84$ & $2.89 \pm 0.86$ & $2.90 \pm 0.69$ \\
OHC (g/g DW) & $1.90 \pm 0.23$ & $2.04 \pm 0.30$ & $2.27 \pm 0.05$ & $1.72 \pm 0.19$ \\
\hline
\end{tabular}

Values are mean \pm SEM, $n=3$. RT: room temperature; dry weight (DW); swelling capacity (SWC); water-holding capacity (WHC); oil-holding capacity $(\mathrm{OHC})$.

\section{Discussion}

Seaweed is highly productive marine organism that is suited to, and capable of growing on non-arable land, to utilise waste materials as sources of nutrients. Seaweed therefore, generally vary from terrestrial plants in morphological and physiological characteristics and so also their chemical compositions, as evident in their appearances. The moisture content of S. Polycystum measured in the present study was slightly higher than was previously documented $(9.95 \%$ DW) [10] in same species collected from Kota Kinabalu (west coast of North Borneo). Furthermore, the ash content is higher, indicating appreciable composition of diverse minerals, compared to that in most land-based plants that are noted to contain ash values ranging from 5 to $10 \%$ [11]. Nonetheless, data for ash content of the species reported in this present study were consistent with that reported for different genera of seaweeds collected elsewhere, globally (12-40\% DW) [12-14]. In addition, protein content of S. Polycystum was within the range noted in the literature for brown seaweeds (3-15\% DW) [14], even though the value for this brown seaweed species was lower when compared to that for red and green seaweed species (10-47\% DW) [10]. Variations in the protein contents of seaweeds may be due to species differences and seasonal changes [15]. High content of protein (of up to $8.65 \%$ ) in this brown seaweed could make it suitable as supplementary food, including animal feed and also, as a valuable resource to replace proteins from other sources. The measurement of low total lipids in S. Polycystum in this study recorded at $3.42 \% \mathrm{DW}$, is consistent with the fact already established in the literature that most seaweed species contain low contents of total lipid $(<5 \% \mathrm{DW})[16,17]$. This is reported to be attributed to the photosynthetic capabilities of seaweed pigments [18]. This notwithstanding, the values recorded in this study were higher than that reported $(0.29 \% \mathrm{DW})$ by other researchers [10] for the same species. Nutritionally, lipid extracts of seaweeds naturally contain varieties of high-value polyunsaturated and monounsaturated fatty acids (FA) that act as catalysts for the antibacterial, antifungal, antiviral and cytotoxic properties of seaweeds [19]. The nutritional content of the S. Polycystum in terms of fibre and carbohydrate makes it a nutritive supplement which makes it an important human food resource. A study has reported that the fibre in seaweed helps to delay the feeling of hunger as it slows down stomach emptying, improves nutrient and mineral absorption thus, retarding hunger pangs [20]. These characteristics of seaweed fibre may be exploited in the design of diets to aid weight loss. Compared to terrestrial plant-derived foods, seaweed possesses similar or even higher amounts of dietary fibre. According to Rasmussen and Morrissey (2007) [21], seaweeds contain average total dietary fibre that could vary between $36 \%$ and $60 \%$ DW. Other studies have attributed the variations in the proximate compositions of Sargassum species measured at different locations to be related to seasonal differences of sample collection, taxonomic entities [22], geographical location of sampling [23] and environmental factors, including degree of salinity, intensity of light [24], temperature $[25,26]$ and availability of nutrients $[27,28]$.

Photosynthetic pigments are important to plant species and they are usually classified into three major categories: chlorophylls $(a, b, c)$, carotenoids (carotene and xantophylls) and phycobilins (phycoerythrin and phycocyanin) [29]. Whereas chlorophylls comprise part of the components required for photosynthesis, the essential role played by carotenoids is to pass captured light energy to the chlorophylls. As photosynthetic pigments are vital components for organic synthesis of food in plants, cellular viability is thus associated with, and very much dependent on the photosynthetic activities of the seaweed [30]. Conse- 
quently, seaweeds distribute themselves in a vertical pattern on seashores and seafloors, an attribute that assists their maximum exposure to sun rays during low tides, as they get submerged under water in high tidal situations. Therefore, seaweeds experience continuous exposure to fluctuations in salinity, turbidity, high light intensity, pollution, temperature and heavy metal stresses, which are all harmful. The protection of these photosynthetic apparatuses against exposure to these stressors is of immense importance for seaweed survival [31]. It is worthy to note that the concentrations of specific photosynthetic pigments in seaweeds vary depending on the morphological structures of the species and the prevailing environmental factors [32]. A research carried out by Pangestuti and Kim, 2011 [29] related to natural pigments derived from marine algae, elucidated various beneficial biological activities to be considered, to select seaweed species for the cosmetics, food and pharmacology industries. Hence, it is no surprise that in the food industry, microalgae like spirulina is edible, as its contents of total carotenoid, chlorophyll $a$ and chlorophyll $b$ were measured as $3.5 \mathrm{mg} \mathrm{g}^{-1}, 5.7 \pm 0.2 \mathrm{mg} \mathrm{g}^{-1}$ and $3.4 \pm 0.3 \mathrm{mg} \mathrm{g}^{-1}$, (on dry weight basis respectively [33] while Chlorella contained $81.81 \mu \mathrm{g} \mathrm{g}^{-1}, 502 \mu \mathrm{g} \mathrm{g}^{-1}$ and $71.9 \mu \mathrm{g} \mathrm{g}^{-1} \mathrm{DW}$ of total carotenoid, chlorophyll $a$ and chlorophyll $b$ respectively $[34,35]$.

Nutritionally, diets containing high $\mathrm{Na} / \mathrm{K}$ ratio are related to the incidence of hypertension, as the ideal ratio suggested is below 1.5. The ratio of $\mathrm{Na} / \mathrm{K}$ measured in the present study (5.19) is relatively high when compared to previously published data (0.16) [10]. This may be attributable to variations in several factors, which include climate, location, waves, salinity, light exposure, $\mathrm{pH}$, nitrogen availability, season, age of the species, metabolic processes and the affinity of the plant for each of these measured elements, among other likely reasons [36-38]. Seaweed, Caulerpa lentillifera (a green seaweed species) and olives (a species of plant) on the other hand, have been shown to have $\mathrm{Na} / \mathrm{K}$ ratios measuring 7.8 and 45.63, respectively [10,39]. The recording of high calcium concentration in S. polycystum is of immense benefit, as it is essential for life. This is because Ca is one of the most important minerals that accumulate in seaweeds in much greater quantities than noted in terrestrial foodstuffs [40]. Additional to assisting in the protection and development of bone microstructure, $\mathrm{Ca}$ also enables muscle contraction, nerve conduction and blood coagulation. Magnesium on the other hand, is a vital element for bones and teeth. Ca and $\mathrm{Mg}$, elements usually found in abundance in seaweeds, are also contained in apples, oranges, carrots and potatoes [41]. This is particularly crucial considering that there is current increasing preference for plant-based diets and lifestyles, leading to exclusion or reduction in the consumption of meat, eggs and dairy products [42]. Micro minerals such as iron (Fe), selenium (Se) and manganese $(\mathrm{Mn})$ contribute significantly to the regular functioning of the human body, even though they are required in small quantities. Notably however, the Fe and Se content measured in this current study was relatively higher than that reported by other authors (68.21 and $1.14 \mathrm{mg} 100 / \mathrm{g}$ DW) [10]. Mn content has been reported to be highest in red seaweed species, particularly in Chondrus Crispus, Palmaria palmata and Gracilaria spp. Those were sampled from different regions of Denmark [43]. Generally, the absorption potential of algae for trace metals is reported to occur via two mechanisms; first, is through a surface reaction that is independent of metabolic factors such as temperature, light, $\mathrm{pH}$, or age of plants. This mechanism seems to be the primary absorption mechanism for $\mathrm{Zn}$. The second process is a slower, active uptake, where metal ions such as $\mathrm{Cu}, \mathrm{Mn}$, Se and $\mathrm{Ni}$ are transported across the cell membrane into the cytoplasm. This second mechanism of absorption is directly dependent on metabolic processes and often differ with temperature, light or as the plant ages [38]. Consequently, the results for minerals content measured in the present study demonstrates that seaweeds species studied has potential to be utilised as a food supplement. This is especially as a source of $\mathrm{Fe}$, to combat iron deficiency disorders in patients with anaemia; selenium, an antioxidant and catalyst for thyroid hormone production [44] and manganese for the formation of bones, connective tissues, sex hormones and blood clotting. Mn is also actively involved in fat and carbohydrate metabolism, absorption of calcium and the regulation of blood sugar, as well as for brain and nerve functions. 
Major constituents of seaweed fibre are fucose, mannose, galactose and uronic acids, which vary based on the type of seaweed of interest [45]. These substances are cross-linked with each other to form complex structures of low to high molecular weight polysaccharides that are resistant to degradation but easily utilised by microorganisms [46]. The fibre component of seaweeds essentially contains structural polysaccharides such as alginate and fucoidan in brown seaweeds, carageenan, agar and porphyran rich in red seaweeds and ulvan found in green seaweeds. In its natural form, the seaweed plant is therefore, rich in polysaccharides, making it a suitable potential candidate for investigations as prebiotic. Accumulating evidence suggests that low molecular weight polysaccharides and oligosaccharides derived from hydrocolloids in seaweeds can act as potential sources for soluble fibre with prebiotic activity [46]. Studies suggest that polysaccharides and oligosaccharides extracted from seaweeds may simulate intestinal function, including fermentation, prevent pathogen adhesion and avoidance and potentially cure inflammatory bowel disease. Anticoagulant, antitumour, anti-inflammatory, antiviral, antihyperlipidemic or antioxidant functions are also shown in certain seaweed polysaccharides [47].

Generally, seaweeds are known to contain medicinally rich metabolites that include steroids, phenols, tannins, saponins, flavonoids, terpenoids and glycosides, which have been extensively studied and used in the pharmaceutical industry. These compounds were also found in abundance in other species of Sargassum such as S. angustifolium, S. oligocystum and S. boveanum [48]. In the present study, the presence of tannins was revealed in methanolic extracts of S. polycystum. Tannins have been found to exhibit antimicrobial properties as they are able to bind to adhesins and involved in enzyme inhibition, substrate deprivation and membrane disruption [49]. Saponins have such specific biological activities as anticancer, anti-inflammatory, antimicrobial and antioxidant properties $[50,51]$. Saponins also have the property to precipitate and coagulate red blood cells [52]. Flavonoids are hydroxylated phenolic substances implicated for their response to antioxidant activity [53]. The present study also demonstrated the presence of steroid in methanolic extracts of S. polycystum. Steroids are known to possess antimicrobial, anticancer, antiarthritic, antiasthma and anti-inflammatory properties and as such, they are considered as very important compounds [54]. Presence of terpenoids have been related to acquisition of cytotoxicity against a variety of cancer cells and cancer prophylaxis, while glycosides may be utilised as food additives and bio preservatives $[55,56]$.

A previous study carried out on three seaweed species, using different physical pretreatment strategies found that the protein pellet isolated from $P$. palmate contained the highest percentage of EAA, at $43.8 \%$, followed by protein from C. crispus containing $40.94 \%$ EAA, while the lowest EAA was found in proteins from F. vesiculosis, at $25.45 \%$. The EAAs found in protein of these three different seaweeds were obtained using classical protein extraction method [57]. The high content of the non-essential amino acids (NEAAs) aspartic and glutamine acids are known to be responsible for the special flavours and tastes of seaweeds [58]. In terms of human health, NEAAs are useful in nucleotide and lipid biosynthesis, maintenance of redox homeostasis and for various allosteric and epigenetic regulatory mechanisms, including other aspects of tumour metabolism. There is considerable interest to target NEAA metabolism for cancer therapy because of their importance in these different functions [59]. Generally, the content of total amount of amino acids in green seaweed is significantly higher than that in red and brown seaweeds, although this contrasts to reports by other researchers [60] on subtropical red and green seaweeds.

The most prevalent metabolite identified and measured in S. polycystum in this present study was n-hexadecanoic acid or palmitic acid C16:0, which is a form of fatty acid in plants. Palmitic acid has been reported to possess antioxidant properties, which displayed cytotoxicity against human colorectal carcinoma cells (HCT-116) [61,62]. This is in contrast to report from a previous study, which revealed linolenic acid, arachidonic acid and eicosapentaenoic acid as the highest metabolite in the same species of seaweed sampled from a different location [10]. Schmid et al., 2014 [63] suggested that besides differences between species, variations in fatty acid concentrations among seaweeds were mostly due 
to abiotic factors such as light, salinity and nutrients. Other metabolites identified in the present study were tetradecanoic acid, cis-vaccenic acid and 15-hydroxypentadecanoic acid. Additionally, 1,2-benzenedicarboxylic acid, mono(2-ethylhexyl) ester (BMEH) is known for its anti-fungal, anti-diabetic, anti-cancer, antioxidant activities and as a potent antimicrobial agent [64,65]. Selvakumar et al., 2019 [66] described that BMEH isolated from marine Streptomyces sp. VITJS4 demonstrated in vitro anti-cancer potential against liver (HepG2) cancer cells. Moreover, 3,7,11,15-tetramethyl-2-hexadecen-1-ol (Phytol) (also measured in the present study) is an important diterpene that possesses antimicrobial, antioxidant and anti-cancer activities $[67,68]$. The ability of phytol for anti-cancer activity may be associated with its ability to remove the hydroxyl radical (free radical) [69]. Benzenepropanoic acid, 3,5-bis(1,1-dimethylethyl)-4-hydroxy- methyl ester on the other hand, exhibits anti-fungal and antioxidant activities [70], while squalene which is vitamin E compound acquired for antidiabetic, anti-inflammatory and antioxidant activities.

Physicochemical properties, including swelling capacity (SWC), water-holding capacity (WHC) and oil-holding capacity (OHC) of S. polycystum define the physiological effects of dietary fibre. It is vital to consider the water associated with fibre while searching the impact of fibre in the diet. The metabolic activity of fibre along the human gut is affected by water [71]. Generally, an increase is noticed in the SWC and WHC of S. polycystum powder with increasing temperature could be due to an increase in the solubility of the fibre component and the protein content of S. polycystum [72]. The SWC and WHC properties of seaweeds are usually related to their polysaccharide and protein characteristics that bind to the polysaccharide cell wall [73]. The differences noted in the seaweed samples with temperature in SWC and WHC may be due to protein conformations and the changes in the number and nature of the protein molecules' water-binding sites [60]. For food industry applications, high WHC values suggest that the seaweed material may be useful as functional component for modifying the texture of meat products and salad dressings to develop low caloric foods. Low-caloric sugar substitutes are also essential for low-calorie food products such as extruded chips, maize flakes, cookies and crackers [74,75]. The observation in the current study that the $\mathrm{OHC}$ of $S$. polycystum at room temperature was lower than that at $37^{\circ} \mathrm{C}$ and $60^{\circ} \mathrm{C}$, but slightly higher at $80^{\circ} \mathrm{C}$ is a desirable attribute in the food industry. $\mathrm{OHC}$ characterises the emulsification properties of $S$. polycystum, where high $\mathrm{OHC}$ value in an ingredient has been shown to allow for the stabilisation of food emulsions in high-fat food products [76]. It is an important functional property of food ingredients that is measured to determine the hydrophobicity of fibre molecules [77].

\section{Materials and Methods}

\subsection{Sample Collection and Preparation}

Fresh brown seaweed, S. polycystum was collected in the morning, by hand during low tides on reef flats, approximately $100 \mathrm{~m}$ from the shore in Teluk Kemang, Port Dickson, Malaysia $\left(2^{\circ} 26^{\prime} \mathrm{N}, 101^{\circ} 51^{\prime} \mathrm{E}\right)$ in September 2019. The collected seaweed sample was cleaned of extraneous materials like epiphytes, sand particles, pebbles and shells by washing with sea water. The samples were separated into two. The first portion of the samples was taken into the herbarium for taxonomic identification. The taxonomic identification was crossed reference with taxonomic books, monographs and reference herbaria. The second portion of clean samples was then placed in transparent polyethylene bags (inside chilled plastic containers) and transported to the research facilities of the Aquatic Animal Health and Therapeutics Laboratory (AquaHealth), Institute of Bioscience, Universiti Putra Malaysia (UPM) Serdang, Malaysia. In the laboratory, the sample was further washed thoroughly with tap water, followed by distilled water and frozen over- night at $-80{ }^{\circ} \mathrm{C}$ in a freezer (Thermo Scientific, Asheville, NC, USA). Frozen seaweed sample was lyophilised in a freeze dryer (Labconco FreeZone, Kansas, USA) until a constant weight of biomass was attained. The dried seaweed sample was subsequently ground to a fine powder with a laboratory-scale blender and sieved using a 200 micron-sized sieve. The fine sample 
powder was collected in screw-capped bottles, labelled appropriately and stored in a freezer maintained at $-80{ }^{\circ} \mathrm{C}$ until further use.

\subsection{Proximate Composition Determination}

Dry matter, ash, crude fat (by ether extraction), crude protein and total dietary fibre contents were analysed using official methods of AOAC (2006) [78]. The moisture content was determined by oven-drying method, by drying $1 \mathrm{~g}$ of sample at $105{ }^{\circ} \mathrm{C}$ until constant weight (AOAC 950.46) in a vacuum oven (Memmert ULM 400, Schwabach, Germany) and the ash content was gravimetrically determined by heating the sample at $550{ }^{\circ} \mathrm{C}$ for $4 \mathrm{~h}$ in a muffle furnace (Carbolite 11/14, Hope Valley, UK) (AOAC 923.03). The fat content was extracted in a Soxtec system with petroleum ether (AOAC 991.36) and the protein content was determined using Kjeltec system ( $\mathrm{N}$ x 6.25) (AOAC 981.10). Crude fibre was determined with successive hydrolysis with $100{ }^{\circ} \mathrm{C} 0.26 \mathrm{~N}$ sulphuric acid $\left(\mathrm{H}_{2} \mathrm{SO}_{4}\right)$ and $0.31 \mathrm{~N}$ sodium hydroxide $(\mathrm{NaOH})$ for $30 \mathrm{~min}$ each in a digital hot plate (AOAC 962.09). Dietary fibre was analysed with enzymatic-gravimetric method (AOAC 991.43). NFE content was calculated by difference;

$$
\text { NFE }=100-(\text { crude protein }+ \text { lipids }+ \text { ash }+ \text { crude fibre })
$$

The results were expressed on dry weight (DW) basis and all measurements were performed in triplicate.

\subsection{Mineral Determination}

In the determination of mineral elements in S. polycystum, $1 \mathrm{~g}$ of sample was dissolved in $1 \mathrm{~mL}$ of nitric acid $\left(\mathrm{HNO}_{3}\right)$ and hydrogen peroxide $\left(\mathrm{H}_{2} \mathrm{O}_{2}\right)$ before it was digested in microwave. The mixture was shaken and filtered using filter paper. The minerals: potassium $(\mathrm{K})$, magnesium $(\mathrm{Mg})$, calcium $(\mathrm{Ca})$, iron $(\mathrm{Fe})$ and manganese $(\mathrm{Mn})$ were determined using an atomic absorption spectrophotometer (AAS) (Hitachi Z-5000, Tokyo, Japan) and an air-acetylene burner was used. Sodium $(\mathrm{Na})$, phosphorus $(\mathrm{P})$ and selenium $(\mathrm{Se})$ were determined using inductive coupled plasma mass spectrometry (ICP-MS) (Perkin Elmer ELAN 9000, Wellesley, MA, USA). The concentrations of the elements were determined from calibration curves of the standard elements. The results were expressed in $\mathrm{mg} \mathrm{100/g} \mathrm{DW}$ basis and all measurements were performed in triplicate.

\subsection{Total Carotenoids and Chlorophyll Content Determination}

Total carotenoids, chlorophylls $a$ and $b$ contents of dried S. polycystum were determined in accordance with slight modifications to the method of Lichtenthaler and Buschmann, (2001) [79]. According to this method, dilution in methanol was carried out for seaweed lipophilic extract and the absorbance of total carotenoids; chlorophyll $a$ and chlorophyll $b$ were measured at 470, 665.2 and $652.4 \mathrm{~nm}$, respectively using a UV-spectrophotometer (Shimadzu UV 1601, Kyoto, Japan) Calculation of the total carotenoids, chlorophyll $a$ and chlorophyll $b$ contents in seaweed lipid sample were performed using the Lichtenthaler equations as follows (with values expressed as $\mu \mathrm{g} / \mathrm{g}$ dry weight $[\mu \mathrm{g} / \mathrm{g} \mathrm{DW}]$ );

$$
\begin{gathered}
\left.\mathrm{C}_{\mathrm{x}+\mathrm{c}}\right)(\mu \mathrm{g} / \mathrm{mL})=\left(1000 \mathrm{~A}_{470}-1.63 \mathrm{C}_{\mathrm{a}}-104.96 \mathrm{C}_{\mathrm{b}}\right) / 221 \\
\mathrm{C}_{\mathrm{a}}(\mu \mathrm{g} / \mathrm{mL})=16.72 \mathrm{~A}_{665.2}-9.16 \mathrm{~A}_{652.4} \\
\mathrm{C}_{\mathrm{b}}(\mu \mathrm{g} / \mathrm{mL})=34.09 \mathrm{~A}_{652.4}-15.28 \mathrm{~A}_{665.2}
\end{gathered}
$$

where, $\mathrm{C}_{(\mathrm{x}+\mathrm{C})}=$ total carotenoids, $\mathrm{C}_{\mathrm{a}}=$ chlorophyll $a, \mathrm{C}_{\mathrm{b}}=$ chlorophyll $b, \mathrm{~A}_{470}=$ absorbance at $470 \mathrm{~nm}, \mathrm{~A}_{665.2}=$ absorbance at $665.2 \mathrm{~nm}, \mathrm{~A}_{652.4}=$ absorbance at $652.4 \mathrm{~nm}$.

\subsection{Amino Acid Determination}

The amino acid analysis of S. polycystum was performed using high performance liquid chromatography (HPLC). The amino acids (AAs) content of S. polycystum was determined 
according to Chan and Matanjun, (2017) [76] with some slight modification. Powder of $S$. Polycystum $(0.30 \mathrm{~g})$ was weighed in glass stoppered test tube and hydrolysed with $5 \mathrm{~mL}$ of $6 \mathrm{~N}$ hydrochloride acid $(\mathrm{HCl})$ at $110^{\circ} \mathrm{C}$ for $24 \mathrm{~h}$. The hydrolysates were then cooled to room temperature and quantitatively transferred into $100 \mathrm{~mL}$ volumetric flask, with $400 \mu \mathrm{L}$ of $50 \mu \mathrm{mol} / \mathrm{mL} \alpha$-aminobutyric acid (AABA) in $0.1 \mathrm{M} \mathrm{HCl}$ added with ultra-pure water. The aliquot was filtered through filter paper before filtering again through a $0.2 \mu \mathrm{m}$ nylon syringe filter. Later, $10 \mu \mathrm{L}$ filtered solution was collected into a microcentrifuge tube for derivatisation process. About $10 \mu \mathrm{L}$ of samples and standards were injected into a HPLC (Waters 2475, Waters Co., Milford, MA, USA) with the flow rate set at $1 \mathrm{~mL} / \mathrm{min}$. The mobile phase used was: (A) AccQ Tag Eluent A ( $200 \mathrm{~mL}$ AccQ Tag to $2 \mathrm{~L}$ of ultrapure water) and (B) HPLC grade acetonitrile (60\%). The mobile phase was filtered through $0.45 \mu \mathrm{m}$ cellulose membrane filters before it was used. All separations were carried out with AccQ Tag column $(3.9 \times 150 \mathrm{~mm}$, particle size $4 \mu \mathrm{m})$. Detection was carried out by a fluorescence detector operated with a $250 \mathrm{~nm}$ excitation and a $395 \mathrm{~nm}$ emission wavelength. The linear gradient condition was set as follows: $100 \% \mathrm{~A}$ at start, $2 \% \mathrm{~B}$ at $0.5 \mathrm{~min}, 9 \% \mathrm{~B}$ at $15 \mathrm{~min}$, $13 \% \mathrm{~B}$ at $19 \mathrm{~min}, 35 \% \mathrm{~B}$ at $33 \mathrm{~min}, 35 \% \mathrm{~B}$ at $35 \mathrm{~min}, 100 \% \mathrm{~B}$ at $36 \mathrm{~min}, 100 \% \mathrm{~B}$ at $39 \mathrm{~min}$, $100 \% \mathrm{~A}$ at $40 \mathrm{~min}$ and $100 \% \mathrm{~A}$ at $50 \mathrm{~min}$. The quantity of each AA was determined from the peak area of known quantity of AA standard mixture and peak area of individual AA in sample that contained internal standard. The amount of each AA in S. polycystum was expressed as mg/g DW basis. All the measurements of AAs were performed in triplicate. The AA score of EAAs was calculated using the following equation:

AA score $(\%)=($ mg EAA in $1 \mathrm{~g}$ of test protein $) /(\mathrm{mg} \text { EAA in } 1 \mathrm{~g} \text { of reference protein })^{*} 100$

\subsection{Metabolite Profile Using Gas Chromatography-Mass Spectrometry Analysis}

Metabolite profile of S. polycystum was analysed by gas chromatography-mass spectrometry (GC-MS). For the metabolite extraction from S. polycystum, $1 \mathrm{~g}$ of powdered samples was dissolved with $50 \mathrm{~mL}$ methanol, and vortexed for $5 \mathrm{~min}$. This solution was extracted by sonication for $30 \mathrm{~min}$ using ultrasonic water bath (Power Sonic 505, Seoul, Korea) at ambient temperature. The solvent extract was then filtered through Whatmann No. 1 filter paper while the dry residue re-extracted with another $50 \mathrm{~mL}$ of methanol for a second round of extraction. The extraction process was subsequently repeated in the same manner for a third round of extraction. The filtered extracts were pooled and evaporated to dryness using a rotary evaporator (N-1001S-WD, with EYELA Oil Bath OSB-2000, Tokyo, Japan) at $30^{\circ} \mathrm{C}$, and stored at $-20^{\circ} \mathrm{C}$ until further analysis. Methalonic extracts were characterised quantitatively via GC-MS, with slight modifications [80] using a Shimadzu QP2010 Plus GC-MS system. In the experimental procedure, $0.5 \mu \mathrm{L}$ of sample was separated on a Zebron ZB5-ms $30 \mathrm{~m} \times 0.25 \mathrm{~mm}$ ID $\times 0.25 \mu \mathrm{m}$ film thickness) column. Splitless injection was performed using a purge time of $1 \mathrm{~min}$. Helium represented the carrier gas at a flow rate of $1 \mathrm{~mL} / \mathrm{min}$. The column temperature was maintained at $50^{\circ} \mathrm{C}$ for $3 \mathrm{~min}$, then programmed at $250{ }^{\circ} \mathrm{C}$ for $10 \mathrm{~min}$ and maintained at $250{ }^{\circ} \mathrm{C}$ for $30 \mathrm{~min}$. The inlet and the detector temperatures were set at $250^{\circ} \mathrm{C}$ and the solvent cut time was set at $4.50 \mathrm{~min}$. Identification of peaks was based on a computer-based program matching the mass spectra with those in the library for National Institute of Standards and Technology (NIST3208 and NIST 08s). This was done by comparing retention time data with that obtained for authentic laboratory standards. Individual detected peak areas were quantified and expressed as percentage of total components detected.

\subsection{Colorimetric Determination of Monosaccharide in S. polycystum}

To determine the concentration of fucose from extracts the method previously described by Dische (1955) [81] was employed. Briefly $4.5 \mathrm{~mL}$ of diluted $\mathrm{H}_{2} \mathrm{SO}_{4}$ with distilled water $(6: 1 \mathrm{v} / \mathrm{v})$ was added to $1 \mathrm{~mL}$ of dilute samples in test tubes. These tubes were placed on ice and allowed to cool for $1 \mathrm{~min}$ while stirring with a glass rod. The samples tubes were boiled in water bath for $10 \mathrm{~min}$ then cooled with tap water. The absorbance was read at 396 and $427 \mathrm{~nm}$ on the spectrophotometer (Shimadzu UV-1601 UV-VIS visible, 
Kyoto, Japan). Cysteine solution $(0.1 \mathrm{~mL})$ was added to the tubes and left to incubate for $30 \mathrm{~min}$ at room temperature then absorbance was read at 396 and $427 \mathrm{~nm}$ once again. The absorbance due to fucose is the difference between reading at 396 and $427 \mathrm{~nm}$. Differences in these measurements (after subtraction from pre-cysteine addition absorbance) were used to directly correlate methyl pentose (L-fucose, L-mannose, glucuronic acid, rhamnose, xylose and galactose) concentration by using a standard curve obtained with a fucose concentration ranging from $5-100 \mu \mathrm{g} / \mathrm{mL}$. Total fucose concentration in $\mathrm{mg}$, was calculated from the formula:

$$
\mathrm{F}=\mathrm{b} \times 0.06 \times \mathrm{V},
$$

where

$\mathrm{F}=$ Quantity of fucose in $\mathrm{mg}$

$\mathrm{b}=$ the difference in absorbance readings

$\mathrm{V}=$ the total volume in $\mathrm{mL}$

$0.06=$ factor converting absorbance to amount of fucose

\subsection{Phytochemical Screening}

Phytochemical examination was carried out for S. polycystum according to standard methods. The dried seaweed was ground into a fine powder and dissolved with $50 \mathrm{~mL}$ methanol, and vortexed for $5 \mathrm{~min}$. This solution was extracted by sonication for $30 \mathrm{~min}$ using ultrasonic water bath (Power Sonic 505, Seoul, Korea) at room temperature. The solvent extract was then filtered through Whatmann No. 1 filter paper while the dried residue re-extracted with another $50 \mathrm{~mL}$ of methanol for a second round of extraction. The extraction process was subsequently repeated in the same manner for a third round of extraction. The filtered extracts were pooled and evaporated to dryness using a rotary evaporator (N-1001S-WD, with EYELA Oil Bath OSB-2000, Tokyo, Japan) at $30{ }^{\circ} \mathrm{C}$, and stored at $-20{ }^{\circ} \mathrm{C}$ until further analysis. For terpenoids, extract was dissolved in $2 \mathrm{~mL}$ of chloroform and evaporated to dryness. To this, $2 \mathrm{~mL}$ of concentrated sulphuric acid, $\mathrm{H}_{2} \mathrm{SO}_{4}$ was added and heated for about $2 \mathrm{~min}$. A greyish colour indicated the presence of terpenoids. The presence of steroids was indicated by the development of a greenish colouration by mixing extract with $2 \mathrm{~mL}$ of chloroform. Then $2 \mathrm{~mL}$ each of concentrated $\mathrm{H}_{2} \mathrm{SO}_{4}$ and acetic acid was poured into the mixture. While for test for phenols and tannins, extract was mixed with $2 \mathrm{~mL}$ of $2 \% \mathrm{FeCl}_{3}$ solution. A blue-green or black colouration indicated the presence of phenols and tannins. Detection for flavonoids was conducted by diluting extract with $2 \mathrm{~mL}$ of sodium hydroxide, $\mathrm{NaOH}$. Mixture turned to intense yellow colouration. Once hydrochloric acid, $\mathrm{HCl}$ was added, the solution became colourless. As for saponins, extract was mixed with $5 \mathrm{~mL}$ of distilled water in a test tube. It was shaken vigorously. Formation of stable foam was taken as an indication for the presence of saponins.

\subsection{Physicochemical Properties}

Physicochemical properties such as swelling, water retention and oil-holding capacity were assessed in S. polycystum using the previously published method [76]. All measurements were performed in triplicate. For water swelling capacity (SWC), $0.50 \mathrm{~g}$ of lyophilised $S$. polycystum powder was mixed with $10 \mathrm{~mL}$ distilled water and stirred in a measuring cylinder before it was left at RT $\left(25^{\circ} \mathrm{C}\right), 37^{\circ} \mathrm{C}, 60^{\circ} \mathrm{C}$ and $80^{\circ} \mathrm{C}$ for $18 \mathrm{~h}$. The swelling volume was measured and expressed as $\mathrm{mL}$ of sample occupied per $\mathrm{g} \mathrm{DW}$ of sample. The water-holding capacity (WHC) of sample was determined by dispersal of $0.50 \mathrm{~g}$ of lyophilised S. polycystum in $25 \mathrm{~mL}$ of distilled water and placed in a pre-weighed centrifuge tube. The dispersion was then stirred and left at RT $\left(25^{\circ} \mathrm{C}\right), 37^{\circ} \mathrm{C}, 60^{\circ} \mathrm{C}$ and $80{ }^{\circ} \mathrm{C}$ for $1 \mathrm{~h}$ before the mixture was centrifuged at $3000 \mathrm{~g}$ for $25 \mathrm{~min}$. The supernatant was discarded, and the moisture content of sample was determined by dehydration in an oven at $50{ }^{\circ} \mathrm{C}$ for $24 \mathrm{~h}$. The results were expressed as g/g DW of sample. The oil-holding capacity (OHC) of lyophilised $S$. polycystum was determined by weighing $0.5 \mathrm{~g}$ of sample and mixed with $20 \mathrm{~mL}$ of corn oil in a pre-weighed centrifuge tube. The mixture was then 
stirred before it was left at $\mathrm{RT}\left(25^{\circ} \mathrm{C}\right), 37^{\circ} \mathrm{C}, 60^{\circ} \mathrm{C}$ and $80^{\circ} \mathrm{C}$ concurrently for $1 \mathrm{~h}$ prior to centrifuging the mixture at $3000 \times g$ for $25 \mathrm{~min}$. The oil supernatant was discarded and measured. The results were expressed as $\mathrm{g} / \mathrm{g}$ DW of sample.

\section{Conclusions}

In conclusion, S. polycystum seaweed is a potential source for many bioactive, nutritionally and physiologically important compounds that could be utilised in the nutraceutical and pharmaceutical industries as sources of food and medicine, respectively. The present study demonstrated that the brown seaweed, S. polycystum is rich in proteins, lipids, carbohydrate and minerals such as $\mathrm{Na}, \mathrm{K}, \mathrm{Ca}, \mathrm{Mg} \mathrm{Fe}$, Se and $\mathrm{Mn}$. From results of the phytochemical investigation of $S$. polycystum extract, the presence was revealed of various secondary metabolites, in which it was discovered that n-hexadecanoic acid, 1,2-benzenedicarboxylic acid, mono(2-ethylhexyl) ester, benzenepropanoic acid, 3,5-bis(1,1dimethylethyl)-4-hydroxy- methyl ester, 1-dodecanol, 3,7,11-trimethyl-, were the most abundant metabolites. The present study also demonstrated the content of pigments (total carotenoids, chlorophylls $a$ and $b$ ) in S. polycystum and that the major constituent of $S$. polycystum fibre included fucose, mannose, galactose, xylose and rhamnose. The physicochemical properties of this seaweed, which included water-holding and swelling capacity were comparable to that in some commercial fibre-rich products. Results of this study therefore, indicate that $S$. polycystum is a potential candidate as a functional food source for human consumption and its cultivation needs to be encouraged.

Author Contributions: M.F.N.: conceptualisation, methodology, investigation, resources, formal analysis, writing - review and editing, project administration. N.H.A.: investigation, methodology, formal analysis, writing-review and editing. S.B.: investigation, methodology, formal analysis, writing-review and editing. W.N.I.W.H.: writing—review and editing. N.A.I.N.M.: investigation, formal analysis, writing - review and editing. M.I.A.: investigation, formal analysis, writing-review and editing. I.-S.M.Y.: writing-review and editing. A.I.: investigation, formal analysis, writingreview and editing. M.A.-P.: conceptualisation, investigation, writing-review and editing. All authors have read and agreed to the published version of the manuscript.

Funding: This work was supported by Universiti Putra Malaysia (UPM) through the Ministry of Higher Education (MoHE) funding of Higher Centres of Excellence (HiCOE) (grant no. 6369100).

Institutional Review Board Statement: Not applicable.

Informed Consent Statement: Not applicable.

Acknowledgments: The authors thank the Laboratory of Aquatic Animal Health and Therapeutics, Institute of Bioscience, Universiti Putra Malaysia for making available all the equipment for the evaluations carried out. We graciously acknowledge the support and assistance of all technical staff for their contributions during sampling, laboratory work and analysis.

Conflicts of Interest: All authors agree to the authorship and submission of the manuscript for peer review. The founding sponsors had no role in the design of the study; in the collection, analyses, or interpretation of data; in the writing of the manuscript, and in the decision to publish the results. There are no conflicts, informed consent, human or animal rights applicable.

\section{References}

1. Nor, A.M.; Gray, T.S.; Caldwell, G.S.; Stead, S.M. A value chain analysis of Malaysia's seaweed industry. J. Appl. Phycol. 2020, 32, 2161-2171. [CrossRef]

2. Collins, K.G.; Fitzgerald, G.F.; Stanton, C.; Ross, R.P. Looking Beyond the Terrestrial: The Potential of Seaweed Derived Bioactives to Treat Non-Communicable Diseases. Mar. Drugs 2016, 14, 60. [CrossRef] [PubMed]

3. Metailler, R.; Aldrin, J.F.; Messager, J.L.; Mevel, G.; Stephan, G. Feeding of European sea bass Dicentrarchus labrax: Role of protein and energy source. J. World Maricult. Sot. 1981, 12, 117-118. [CrossRef]

4. Watanabe, T.; Kitajima, C.; Fujita, S. Nutritional values of live organisms used in Japan for mass propagation of fish: A review. Aquaculture 1983, 34, 115-143. [CrossRef]

5. Bell, M.V.; Henderson, R.J.; Sargent, J.R. The role of polyunsaturated fatty acids in fish. Comp. Biochem. Physiol. B Biochem. Mol. Biol. 1986, 83, 711-719. [CrossRef] 
6. Kanazawa, A.; Teshima, S.I.; Kazuo, O. Relationship between essential fatty acid requirements of aquatic animals and the capacity for bioconversion of linolenic acid to highly unsaturated fatty acids. Comp. Biochem. Physiol. B Biochem. Mol. Biol. 1979, 63, 295-298. [CrossRef]

7. Bagchi, S. Red-algae derivative could be useful adjunct to HPV vaccine. Lancet Oncol. 2006, 7, 623. [CrossRef]

8. Hafting, J.T.; Critchley, A.T.; Cornish, M.L.; Hubley, S.A.; Archibald, A.F. On-land cultivation of functional seaweed products for human usage. J. Appl. Phycol. 2012, 24, 385-392. [CrossRef]

9. Cherry, P.; O’Hara, C.; Magee, P.J.; McSorley, E.M.; Allsopp, P.J. Risks and benefits of consuming edible seaweeds. Nutr. Rev. 2019, 77, 307-329. [CrossRef]

10. Matanjun, P.; Mohamed, S.; Mustapha, N.M.; Muhammad, K. Nutrient content of tropical edible seaweeds, Eucheuma cottonii, Caulerpa lentillifera and Sargassum polycystum. J. Appl. Phycol. 2009, 21, 75-80. [CrossRef]

11. Rupérez, P. Mineral content of edible marine seaweeds. Food Chem. 2002, 79, 23-26. [CrossRef]

12. Wong, K.; Cheung, P.C. Influence of drying treatment on three Sargassum species. J. Appl. Phycol. 2001, 13, 43-50. [CrossRef]

13. Heo, S.J.; Lee, G.W.; Song, C.B.; Jeon, Y.J. Antioxidant activity of enzymatic extracts from brown seaweeds. Algae 2003, $18,71-81$. [CrossRef]

14. Kumar, S.; Sahoo, D.; Levine, I. Assessment of nutritional value in a brown seaweed Sargassum wightii and their seasonal variations. Algal Res. 2015, 9, 117-125. [CrossRef]

15. Galland-Irmouli, A.V.; Fleurence, J.; Lamghari, R.; Luçon, M.; Rouxel, C.; Barbaroux, O.; Bronowicki, J.P.; Villaume, C.; Guéant, J.L. Nutritional value of proteins from edible seaweed Palmaria palmata (dulse). J. Nutr. Biochem. 1999, 10, 353-359. [CrossRef]

16. Montgomery, W.; Gerking, S. Marine macroalgae as foods for fishes: An evaluation of potential food quality. Env. Biol. Fish. 1980, 5, 143-153. [CrossRef]

17. Kumari, P.; Kumar, M.; Gupta, V.; Reddy, C.R.K.; Jha, B. Tropical marine macroalgae as potential sources of nutritionally important PUFAs. Food Chem. 2010, 120, 749-757. [CrossRef]

18. Özçimen, D.; İnan, B. An overview of bioethanol production from algae. In Biofuels—Status and Perspective; Biernat, K., Ed.; InTech: Rijeka, Croatia, 2015; pp. 141-162.

19. Goecke, F.; Hernandez, V.; Bittner, M.; Gonzalez, M.; Becerra, J.; Silva, M. Fatty acid composition of three species of Codium (Bryopsidales, Chlorophyta) in Chile. Rev. Biol. Mar. Oceanogr. 2010, 45, 325-330. [CrossRef]

20. de Jesus Raposo, M.F.; de Morais, A.M.; de Morais, R.M. Emergent Sources of Prebiotics: Seaweeds and Microalgae. Mar. Drugs 2016, 14, 1-27. [CrossRef] [PubMed]

21. Rasmussen, R.S.; Morrissey, M.T. Marine biotechnology for production of food ingredients. In Advances in Food and Nutrition Research; Taylor, S.L., Ed.; Elsevier: New York, NY, USA, 2007; Volume 52, pp. 237-292.

22. Khotimchenko, S.V. Lipids from the marine alga Gracilaria verrucosa. Chem. Nat. Compd. 2005, 41, 285-288. [CrossRef]

23. Kendel, M.; Wielgosz-Collins, G.; Bertrand, S.; Roussakis, C.; Bourgougnon, N.; Bedoux, G. Lipid composition, fatty acids and sterols in the seaweeds Ulva armoricana, and Solieria chordalis from Brittany (France): An analysis from nutritional, chemotaxonomic and antiproliferative activity perspectives. Mar. Drugs 2015, 13, 5606-5628. [CrossRef] [PubMed]

24. Hotimchenko, S.V. Fatty acid composition of algae from habitats with varying amounts of illumination. Russ. J. Mar. Biol. 2002, 28, 218-220. [CrossRef]

25. Nelson, M.M.; Phleger, C.F.; Nichols, P.D. Seasonal lipid composition in macroalgae of the Northeastern Pacific Ocean. Bot. Mar. 2002, 45, 58-65. [CrossRef]

26. Hold, S.L.; Kraan, S. Bioactive compounds in seaweed: Functional food applications and legislation. J. Appl. Phycol. 2011, 23, 543-597. [CrossRef]

27. Hu, Q.; Sommerfeld, M.; Jarvis, E.; Ghirardi, M.; Posewitz, M.; Seibert, M.; Darzins, A. Microalgal triacylglycerols as feedstocks for biofuel production: Perspectives and advances. Plant J. 2008, 54, 621-639. [CrossRef]

28. Rodolfi, L.; Chini Zittelli, G.; Bassi, N.; Padovani, G.; Biondi, N.; Bonini, G.; Tredici, M.R. Microalgae for oil: Strain selection, induction of lipid synthesis and outdoor mass cultivation in a low-cost photobioreactor. Biotechnol. Bioeng. 2009, 102, 100-112. [CrossRef] [PubMed]

29. Pangestuti, R.; Kim, S.K. Biological activities and health benefit effects of natural pigments derived from marine algae. J. Funct. Foods 2011, 3, 255-266. [CrossRef]

30. Juneja, A.; Ceballos, R.M.; Murthy, G.S. Effects of Environmental Factors and Nutrient Availability on the Biochemical Composition of Algae for Biofuels Production: A Review. Energies 2013, 6, 4607-4638. [CrossRef]

31. Nejrup, L.B.; Pedersen, M.F. The effect of temporal variability in salinity on the invasive red alga Gracilaria vermiculophylla. Eur. J. Phycol. 2012, 47, 254-263. [CrossRef]

32. Heriyanto, J.A.; Shioi, Y.; Limantara, L.; Brotosudarmo, T.H. Analysis of pigment composition of brown seaweeds collected from Panjang Island, Central Java, Indonesia. Philipp. J. Sci. 2017, 146, 323-330.

33. Marzorati, S.; Schievano, A.; Idà, A.; Verotta, L. Carotenoids, Chlorophylls and Phycocyanin from Spirulina. Supercritical CO2 and Water Extraction Methods for Added Value Products Cascade. Green Chem. 2020, 22, 187-196. [CrossRef]

34. Othman, R.; Noh, N.; Nurrulhidayah, A.F.; Anis Hamizah, H.; Jamaludin, M.A. Determination of natural carotenoid pigments from freshwater green algae as potential halal food colorants. Int. Food Res. J. 2017, 24, 468-471.

35. Gonzalez, L.E.; Bashan, Y. Increased growth of the microalga Chlorella vulgaris when coimmobilized and cocultured in alginate beads with the plantgrowth-promoting bacterium Azospirillum brasilense. Appl. Environ. Microbiol. 2000, 66, 1527-1531. [CrossRef] 
36. Sánchez-Rodríguez, I.; Huerta-Diaz, M.A.; Choumiline, E.; Holguín-Quiñones, O.; Zertuche-González, J.A. Elemental concentrations in different species of seaweeds from Loreto Bay, Baja California Sur, Mexico: Implications for the geochemical control of metals in algal tissue. Environ. Pollut. 2001, 114, 145-160. [CrossRef]

37. Marinho-Soriano, E.; Fonseca, P.C.; Carneiro, M.A.A.; Moreira, W.S.C. Seasonal variation in the chemical composition of two tropical seaweeds. Bioresour. Technol. 2006, 97, 2402-2406. [CrossRef]

38. Kumar, M.; Kumari, P.; Trivedi, N.; Shukla, M.K.; Gupta, V.; Reddy, C.R.K.; Jha, B. Minerals, PUFAs and antioxidant properties of some tropical seaweeds from Saurashtra coast of India. J. Appl. Phycol. 2011, 23, 797-810. [CrossRef]

39. Ortega-Calvo, J.J.; Mazuelos, C.; Hermosin, B.; Sáiz-Jiménez, C. Chemical composition of Spirulina and eukaryotic algae food products marketed in Spain. J. Appl. Phycol. 1993, 5, 425-435. [CrossRef]

40. MacArtain, P.; Gill, C.I.; Brooks, M.; Campbell, R.; Rowland, I.R. Nutritional value of edible seaweeds. Nutr. Rev. 2007, 65, 535-543. [CrossRef] [PubMed]

41. M. Cardoso, S.; G. Carvalho, L.; J. Silva, P.; S. Rodrigues, M.; R. Pereira, O.; Pereira, L. Bioproducts from seaweeds: A review with special focus on the Iberian Peninsula. Curr. Org. Chem. 2014, 18, 896-917. [CrossRef]

42. Circuncisão, A.R.; Catarino, M.D.; Cardoso, S.M.; Silva, A.M.S. Minerals from Macroalgae Origin: Health Benefits and Risks for Consumers. Mar. Drugs 2018, 16, 400. [CrossRef] [PubMed]

43. Parjikolaei, B.R.; Bruhn, A.; Eybye, K.L.; Larsen, M.M.; Rasmussen, M.B.; Christensen, K.V.; Fretté, X.C. Valuable biomolecules from nine North Atlantic red macroalgae: Amino acids, fatty acids, carotenoids, minerals and metals. Nat. Resour. 2016, 7, 157-183. [CrossRef]

44. Rayman, M.P. The importance of selenium to human health. Lancet 2000, 356, 233-241. [CrossRef]

45. Dierick, N.; Ovyn, A.; De Smet, S. In vitro assessment of the effect of intact marine brown macro-algae Ascophyllum nodosum on the gut flora of piglets. Livest. Sci. 2010, 133, 154-156. [CrossRef]

46. Warrand, J. Healthy polysaccharides -The Next Chapter in Food Products. Food Technol. Biotech. 2006, 44, 355-370.

47. Lopez-Santamarina, A.; Miranda, J.M.; Mondragon, A.D.C.; Lamas, A.; Cardelle-Cobas, A.; Franco, C.M.; Cepeda, A. Potential Use of Marine Seaweeds as Prebiotics: A Review. Molecules 2020, 25, 1004. [CrossRef]

48. Mehdinezhad, N.; Ghannadi, A.; Yegdaneh, A. Phytochemical and biological evaluation of some Sargassum species from Persian Gulf. Res. Pharm. Sci. 2016, 11, 243-249. [PubMed]

49. Guo, J.; Sun, W.; Kim, J.P.; Lu, X.; Li, Q.; Lin, M.; Mrowczynski, O.; Rizk, E.B.; Cheng, J.; Qian, G.; et al. Development of tannin-inspired antimicrobial bioadhesives. Acta Biomater. 2018, 72, 35-44. [CrossRef] [PubMed]

50. Sidana, J.; Singh, B.; Sharma, O.P. Saponins of Agave: Chemistry and bioactivity. Phytochemistry 2016, 130, 22-46. [CrossRef]

51. Güçlü-Üstündağ, Ö.; Mazza, G. Saponins: Properties, applications and processing. Crit. Rev. Food Sci. Nutr. 2007, 47, 231-258. [CrossRef]

52. Yadav, R.N.S.; Agarwala, M. Phytochemical analysis of some medicinal plants. J. Phytol. 2011, 3, 10-14.

53. Sytar, O.; Hemmerich, I.; Zivcak, M.; Rauh, C.; Brestic, M. Comparative analysis of bioactive phenolic compounds composition from 26 medicinal plants. Saudi. J. Biol. Sci. 2018, 25, 631-641.

54. Sudha, T.; Chidambarampillai, S.; Mohan, V.R. GC-MS analysis of bioactive components of aerial parts of Fluggea leucopyrus Willd. (Euphorbiaceae). J. Appl. Pharm. Sci. 2013, 3, 126-130.

55. Huang, M.; Lu, J.J.; Huang, M.Q.; Bao, J.L.; Chen, X.P.; Wang, Y.T. Terpenoids: Natural products for cancer therapy. Expert Opin. Investig. Drugs 2012, 21, 1801-1818. [CrossRef]

56. Cuevas, M.; Garcia, J.F.; Hodaifa, G.; Sánchez, S. Oligosaccharides and sugars production from olive stones by autohydrolysis and enzymatic hydrolysis. Ind. Crops. Prod. 2015, 70, 100-106. [CrossRef]

57. O' Connor, J.; Meaney, S.; Williams, G.A.; Hayes, M. Extraction of Protein from Four Different Seaweeds Using Three Different Physical Pre-Treatment Strategies. Molecules 2020, 25, 1-11. [CrossRef] [PubMed]

58. Mabeau, S.; Cavaloc, E.; Fleurence, J.; Lahaye, M. New seaweed based ingredients for the food industry. Int. Food Ing. 1992, 3, 38-45.

59. Choi, B.-H.; Coloff, J.L. The Diverse Functions of Non-Essential Amino Acids in Cancer. Cancers 2019, 11, 675. [CrossRef]

60. Wong, K.; Cheung, P.C. Nutritional evaluation of some subtropical red and green seaweeds: Part I-Proximate composition, amino acid profiles and some physico-chemical properties. Food Chem. 2000, 71, 475-482. [CrossRef]

61. Mujeeb, F.; Bajpai, P.; Pathak, N. Phytochemical Evaluation, Antimicrobial Activity, and Determination of Bioactive Components from Leaves of Aegle marmelos. BioMed Res. Int. 2014, 2014, 497606. [CrossRef] [PubMed]

62. Ravi, L.; Krishnan, K. Cytotoxic potential of N-hexadecanoic acid extracted from Kigelia pinnata leaves. Asian. J. Cell Biol. 2017, 12, 20-27.

63. Schmid, M.; Guihéneuf, F.; Stengel, D.B. Fatty acid contents and profiles of 16 macroalgae collected from the Irish Coast at two seasons. J. Appl. Phycol. 2014, 26, 451-463. [CrossRef]

64. Syeda, F.A.; Habib-Ur- Rehman, M.I.; Choudahry2; Atta-ur-Rahman2. Gas Chromatography-Mass Spectrometry (GC-MS) analysis of petroleum ether extract (oil) and bioassays of crude extract of Iris germanica. Int. J. Genet. Mol. Biol. 2011, 3, 95-100.

65. Bagavathi, P.E.; Ramasamy, N. GCMS analysis of phytocomponents in the ethanol extract of Polygonum chinense L. Pharmacogn. Res. 2012, 4, 11-14. 
66. Selvakumar, J.N.; Chandrasekaran, S.D.; Doss, G.P.C.; Kumar, T.D. Inhibition of the ATPase Domain of Human Topoisomerase IIa on HepG2 Cells by 1, 2-benzenedicarboxylic Acid, Mono (2-ethylhexyl) Ester: Molecular Docking and Dynamics Simulations. Curr. Cancer Drug Targets 2019, 19, 495-503. [CrossRef]

67. Pejin, B.; Kojic, V.; Bogdanovic, G. An insight into the cytotoxic activity of phytol at in vitro conditions. Nat. Prod. Res. 2014, 28, 2053-2056. [CrossRef] [PubMed]

68. Song, Y.; Cho, S.K. Phytol induces apoptosis and ROS-mediated protective autophagy in human gastric adenocarcinoma AGS cells. Biochem. Anal. Biochem. 2015, 4, 4-11.

69. Santos, C.C.D.M.P.; Salvadori, M.S.; Mota, V.G.; Costa, L.M.; de Almeida, A.A.C.; de Oliveira, G.A.L.; Costa, J.P.; de Sousa, D.P.; de Freitas, R.M.; de Almeida, R.N. Antinociceptive and antioxidant activities of phytol in vivo and in vitro models. Neurosci. J. 2013, 949452. [CrossRef]

70. Bashir, A.; Ibrar, K.; Shumaila, B.; Sadiq, A. Chemical composition and antifungal, phytotoxic, brine shrimp cytotoxicity, insecticidal, and antibacterial activities of the essential oils of Acacia modesta. J. Med. Plants Res. 2012, 6, 4653-4659.

71. Gómez-Ordóñez, E.; Jiménez-Escrig, A.; Rupérez, P. Dietary fibre and physicochemical properties of several edible seaweeds from the northwestern Spanish coast. Food Res. Int. 2010, 43, 2289-2294. [CrossRef]

72. Shanmuganathan, B.; Pandima Devi, K. Evaluation of the nutritional profile and antioxidant and anti-cholinesterase activities of Padina gymnospora (Phaeophyceae). Eur. J. Phycol. 2016, 51, 482-490. [CrossRef]

73. Benjama, O.; Masniyom, P. Nutritional composition and physicochemical properties of two green seaweeds (Ulva pertusa and $U$. intestinalis) from the Pattani Bay in Southern Thailand. Songklanakarin. J. Sci. Technol. 2011, 33, 575-583.

74. Carvalho, A.F.U.; Portela, M.C.C.; Sousa, M.B.; Martins, F.S.; Rocha, F.C.; Farias, D.F.; Feitosa, J.P.A. Physiological and physicochemical characterization of dietary fibre from the green seaweed Ulva fasciata Delile. Braz. J. Biol. 2009, 69, 969-977. [CrossRef]

75. Grigelmo-Miguel, N.; Martôân-Belloso, O. Characterization of dietary fiber from orange juice extraction. Food Res. Int. 1999, 31, 355-361. [CrossRef]

76. Chan, P.T.; Matanjun, P. Chemical composition and physicochemical properties of tropical red seaweed, Gracilaria changii. Food Chem. 2017, 221, 302-310. [CrossRef]

77. Lopez-Cervantes, J.; Sanchez-Machado, D.I.; Campas-Baypoli, O.N.; Bueno-Solano, C. Functional properties and proximate composition of cactus pear cladodes flours. Food Sci. Technol. (Campinas) 2011, 31, 654-659. [CrossRef]

78. AOAC. Official Methods of Analysis of AOAC International, 18th ed.; AOAC International: Arlington, VA, USA, 2006; Volumes I-II.

79. Lichtenthaler, H.K.; Buschmann, C. Chlorophylls and Carotenoids: Measurement and Characterization by UV-VIS Spectroscopy, Current Protocols in Food Analytical Chemistry; Wiley: New York, NY, USA, 2001; pp. F4.3.1-F4.3.8.

80. Nazarudin, M.F.; Isha, A.; Mastuki, S.N.; Ain, N.M.; Mohd Ikhsan, N.F.; Abidin, A.Z.; Aliyu-Paiko, M. Chemical Composition and Evaluation of the $\alpha$-Glucosidase Inhibitory and Cytotoxic Properties of Marine Algae Ulva intestinalis, Halimeda macroloba, and Sargassum ilicifolium. Evid. Based Complementary Altern. Med. 2020, 2753945. [CrossRef]

81. Dische, Z. New color reaction for determination of sugars in polysaccharides. Methods Biochem. Anal. 1955, 2, 313-358. 